\title{
Hubungan Antara Pola Asuh Berwawasan Jender Dengan Cinderella Complex
}

\author{
Neneng Anggriany \\ Yulianti Dwi Astuti \\ Universitas Islam Indonesia
}

\begin{abstract}
This study is aimed at finding a relationship between child rearing practice using gender perspective and cinderella complex. The term cinderella complex is used to indicate the tendency among women/female to believe that aspirations for independence, as it relates to their specific gender, is inappropriate. Women who show cinderella complex will see themselves as in need fornuturance, having inherent need for protection and help from other people. The proposed hypothesis was that there is a negative relationship between child rearing practice using gender perspective and cinderella complex. The particlpants of the study were 250 female college students from one private university in Yogyakarta, with age ranging from 19-25 years. The data gathered were analyzed using Pearson product moment correlation. The result of the study confirmed the hypothesis: There is a significant negative correlation between child rearing practice using gender perspective with cinderelle complex. Practical implications and relevance for future studies are dis. cussed.
\end{abstract}

Key words : Child rearing practice, gender perspectives, Cinderella complex.

\section{PENGANTAR}

$S$ tereotipe tentang perempuan dengan segala atribut kelemahan, ketergantungan dan keterbatasannya membuat posisi perempuan benar-benar tidak diuntungkan. Perempuan diberi label sebagai makhluk yang emosionak, lemah-lembut, tergantung, kurang rasional, dan tidak tegas.

Tidak heran jika pada akhirnya bentukan budaya tersebut dianggap kodrat Tuhan. sehingga semakin lama mempengaruhi perkembangan emosi, visi dan ideologi masing-masing jenis kelamin (Fakih, 1996). Seperti yang dikemukakan Hurlock (1999). bahwa penggolongan peran jenis mem- pengaruhí perilaku, penilaian diri, cita-cita, prestasi, minat, sikap terhadap lawan jenis dan penampilan. Anak perempuan menyadari bahwa peran jenis yang harus diperankan lebih rendah daripada peran anak laki-laki. Kesadaran tersebut mengakibatkan menurunnya penilaian diri.

Pengaruh budaya patriarkhis tersebut menyebabkan perempuan dididik, diasuh dan dibesarkan dengan mengkondisikan mereka sebagal makhluk lemah, sehingga akhirnya memunculkan ketergantungan. Ketergantungan yang ditunjukkan dengan ketakutan akan kemandirian ini disebut oleh Dowling 
sebagai Cinderella Complex, yakni ketergantungan perempuan secara psikologis dimana terdapat keinginan yang kuat untuk dirawat dan dilindungi orang lain (laki-laki) serta keyakinan bahwa sesuatu dari luarlah yang akan menolongnya (Dowling, 1981).

Ketakutan akan kemandirian ini mengakibatkan perempuan tidak berani memanfaatkan kemampuan otak dan kreativitasnya secara maksimal. Kondisi ini dilatarbelakangi oleh standar sosial yang memposisikan wanita pada sektordomestik yang tidak perlu mengejar prestasi (Haryono, 2000). Implikasinya, walaupun peluang bagi perempuan untuk mengaktualisasikan dirinya semakin terbuka, perempuan justru cenderung raguragu untuk mengambil kesempatan tersebut.

Berdasarkan pengalaman pribadi dan interaksi dengan sesama mahasiswi, peneliti melihat bahwa rata-rata mahasiswi kurang terlibat aktif dalam lembaga kemahasiswaan yang menuntut keman-dirian dan komitmen. Kecenderungan lain terlihat dari kurangnya inisiatif dan kurangnya kepercayaan pada kemampuan diri sendiri dalam bertindak atau meme-cahkan suatu persoalan, serta sering menunggu pihak lain terutama laki-laki untuk memberikan alternatif dan solusi terhadap suatu persoalan. Hal ini tentu dapat mengganggu perkembangan pribadi wanita karena kualitas kemandirian sangatlah dibutuhkan dalam menghadapi kemajuan jaman yang semakin cepat sekarang ini.

Cinderella Complex, menurut Dowling ditanamkan sejak masa kanak-kanak melalui proses belajar dari lingkungan. John Stuart Mill (Budiman, 1981) seorang ahli filsafat Inggris mengatakan bahwa sifat kewanitaan sebenamya adalah hasil pemupukan masyarakat melalui sistem pendidikan. Asumsi ini sesuai dengan teori Bandura bahwa praktek pengasuhan, keadaan keluarga dan jenis kelamin akan mempengaruhi kemasakan sosial anak, dimana hal tersebut akan mempengaruhi seseorang dalam bersikap.

Ketidakadilan yang menimpa perempuan dan laki-laki sesungguhnya terjadi akibat stereotipe dan budaya yang disosialisasikan, dinternalișasikan bahkan dibakukan oleh segenap aspek bahkan melibatkan hukum dan agama sebagai alat legitimasi. Tidak dapat dipungkiri bahwa salah satu aspek yang ikut memperkuat peran Jender tersebut terkait dengan pola asuh. Anak biasanya diasuh berdasarkan perilaku yang diterima oleh lingkungan berdasarkan jenis kelamin. sehingga menciptakan pola asuh yang tidak berwawasan jender. Pola tersebut tidak hanya terjadi dalam lingkup pendidikan keluarga tetapi jug a dalam pendidikan formal seperti di sekolah. Pola asuh berwawasan jender adalah pola asuh yang didasarkan pada nilai-nilai jender yang lebih memberikan peluang terhadap akses. partisipasi dan penguasaan kepada laki-laki dan perempuan (baik orang tua maupun anak) terhadap berbagai hal dengan adil dan proporsional. Penelitian ini bertujuan untuk mengetahui apakah ada hubungan antara pola asuh berwawasan jender dengan Cinderelta Complexpada perempuan.

\section{TINJAUAN PUSTAKA}

\section{Cinderelta Complex}

Pada tahun 1981, dalam bukunya yang berjudul The Cinderella Complex; Womans Hidden Fear From In-dependence. Dowling mencetuskan istilah Cinderella Complex ini untuk pertama kalinya dan menjelaskan bahwa Cinderella Complex dicetuskan berdasarkan pengalaman pribadi. Setelah melakukan berbagai penyelidikan dan penelitian ternyata sindrom ini dialami oleh banyak perempuan. Bahkan sudah mendarah daging pada diri perempuan df seluruh dunia dan seluruh kebudayaan. Hanya saja perempuan seringkali tidak menyadari.

Sindrom yang sangat meng-hebohkan pada era 80-an, yang disebut Cinderella Complex tersebut adalah ketergantungan secara psikologis pada perempuan dimana terdapat keinginan yang kuat untuk dirawat, dilindungi orang lain (laki-laki) dan keyakinan bahwa sesuatu dari luarlah yang akan menolongnya 
(Dowling, 1981). Sindrom ketakutan akan kemandirian ini merupakan kekuatan utama yang melumpuhkan perempuan, sehingga tidak berani memanfaatkan sepenuhnya kekuatan olak dan kreativitasnya.

Seiring dengan modernisasi dan globalisasi dari segenap aspek kehidupan, peluang perempuan untuk terlibat aktif dan mengaktualisasikan diri dalam berbagai kesempatan semakin terbuka luas. Bersamaan dengan terbukanya kesempatan tersebut muncul pula segudang tuntutan baru. Perempuan tidak dapat lagi mengandakan orang lain yang dianggap lebih kuat sebagai sandaran, sebaliknya mereka dituntut untuk memiliki sikap yang otentik, jujur, bebas dan mandiri.

Namun demikian, kenyataannya perempuan justru mengalami ketakutan ketika mendapatkan kebebasan tersebut. Perempuan telah terkondisi-kan untuk selalu tergantung, tidak mempunyai nilai-nilai sendiri, serta tidak mempunyai kesejatian identitas dir selain mengikuti status ayah bila dia masih anak-anak, mengikuti status suami blla sudah berkeluarga atau status anak-anaknya ketika sudah tua. Menurut Symonds (Dowling 1981) hal ini terjadi karena perempuan tidak mau mengalami kecemasan yang merupa-kan bagian intrinsik dari proses perkembangan. Semasa kanak-kanak perempuan tidak diajarkan untuk bersikap asertif dan mandiri.

Hal ini tentunya akibat bentukan budaya dan norma sosial yang selama ini berlaku. Perempuan telah dikondisikan untuk menghindari segala sesuatu yang menakutkan dan mengerjakan segala sesuatu yang mudah dan nyaman. Perempuan tidak dilatih untuk untuk bebas dan mandiri, tetapi justru dididik dan dilatih untuk tergantung. Hal tersebut akan berpengaruh secara psikis, dan pada akhirnya menjadi pribadi yang tidak terbiasa untuk menghadapi ketakutan, persaingan, tantangan dan terus maju menghadapi segala rintangan. Bahkan menurut psikolog Coburn (Dowling, 1981), setiap kali perempuan menghadapi hidup yang semakin berat, kemungkinan untuk menyerah dan masuk ke dalam perlindungan pria selalu ada. Hal ini mengurangi kuatnya keinginan untuk bertahan mandiri.

Perempuan yang mengalami Cinderella Complex menunjukkan rendahnya kemandirian. Adapun aspek-aspek Cinderella Complex adalah:

1. Mengharapkan pengarahan orang lain.

Ketergantungan pada perempuan telah mematikan inisiatif dan orisinalitasnya. Akibalnya perempuan selalu ragu-ragu dalam bertindak. Sesuatu hal dapat dikerjakan apabila sudah mendapatkan pengesahan secara sosial (Dowling, 1981). Tindakan atau keputusan akan diambil apabila sudah melalui tahap meminta pendapat dan pengarahan orang lain.

\section{Kontrol diri eksternal.}

Aspek ini terlihat, ketika perempuan mendapatkan keberhasilan mereka berhenti pada titik tertentu dan tidak ingin meraih keberhasilan yang lebih jauh lagi (Dowling. 1981). Hasil penelitian menunjukkan bahwa perempuan cenderung mengatribusikan atau melekatkan keberhasilan mereka kepada sumber-sumber luar, misalnya soal keberuntungan. Selain itu cenderung merasa tidak mempunyai kontrol untuk memecahkan masalah sendiri atau untuk mempengaruhi lingkungan (Masrun dkk, 1986).

\section{Rendahnya harga diri.}

Menurut Bardwick (1971), pada diri perempuan terdapat kurangnya harga diri. Akibatnya, seringkali menekan inisiatif dan membuang aspirasinya. Hal ini terkait juga dengan perasaan tidak aman yang sangat mendalam serta ketidakpastian mengenai kemampuan serta nilai diri mereka. Kurangnya harga diri berkaitan erat dengan kecemasan, perasaan lemah, lidak mampu. Misalnya, dalam mengikuti suatu tes, ujian, atau berbicara di hadapan umum, kecemasan yang dialami perempuan lebih tinggi dibanding lakjlaki(Dowling, 1981). 


\section{Tabel 1}

\section{Stereotipe Peran Jenis yang Sederajat}

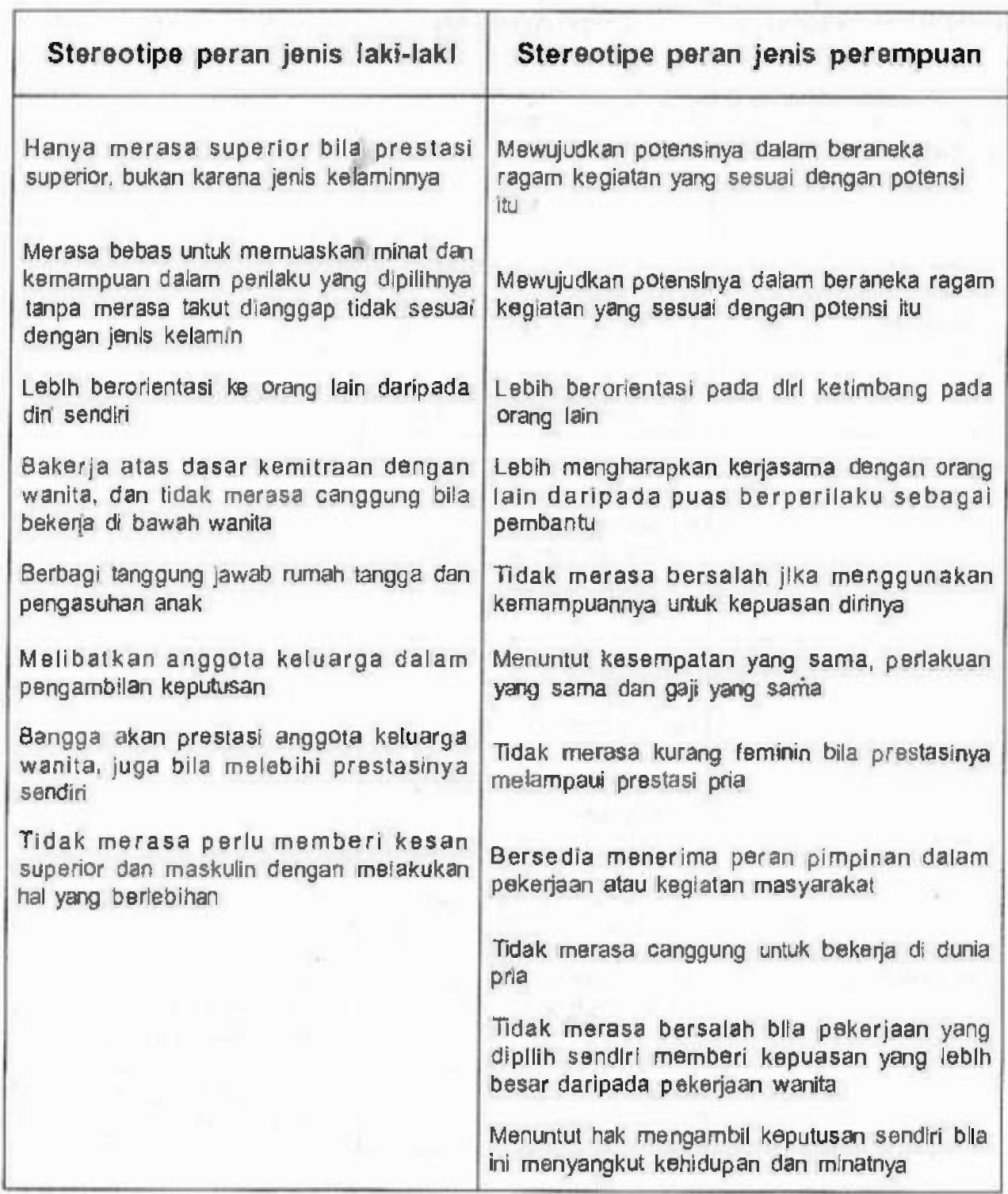


Tabel 2

Aspek-aspek Pola Asuh Berwawasan Jender

\begin{tabular}{|c|c|c|}
\hline ASPEK PENGASUHAN & $\begin{array}{l}\text { BERWAWASAN } \\
\text { JENDER }\end{array}$ & $\begin{array}{c}\text { TIDAK BERWAWASAN } \\
\text { JENDER }\end{array}$ \\
\hline $\begin{array}{l}\text { Permahaman tanggung jawab } \\
\text { pengasuhan }\end{array}$ & $\begin{array}{l}\text { Ayah dan ibu memilik! } \\
\text { tanggung jawab yang sama }\end{array}$ & $\begin{array}{l}\text { Secara esensial ayah dan } \\
\text { ibu memiliki tanggung jawab } \\
\text { berbeda, dimana cenderung } \\
\text { memberikan beban lebih dan } \\
\text { tidak adil tehadap ibu. }\end{array}$ \\
\hline $\begin{array}{l}\text { Wewenang dan proses } \\
\text { pengambilan keputusan } \\
\text { pengasuhan }\end{array}$ & $\begin{array}{l}\text { 1. Ayah dan ibu memiliki } \\
\text { wewenang yang proporsional } \\
\text { dan fungsional } \\
\text { 2. Pengambilan keputusan } \\
\text { dilakukan secara demokratis }\end{array}$ & $\begin{array}{l}\text { 1. Ayah memiliki wewenang } \\
\text { yang lebih dominan dari } \\
\text { pada ibu } \\
\text { 2. Pengambilan keputusan } \\
\text { dilakukan secara oloriter }\end{array}$ \\
\hline $\begin{array}{l}\text { Pembagian tugas } \\
\text { pengasuhan }\end{array}$ & $\begin{array}{l}\text { 1. Ayah dan ibu memllikl } \\
\text { tugas yang sama temadap } \\
\text { pengasuhan } \\
\text { 2. Adamya pembagian tugas } \\
\text { hanyalah menpakan } \\
\text { masalah teknis semata }\end{array}$ & $\begin{array}{l}\text { Pengasuhan semata-mata } \\
\text { adalah tugas ibu. }\end{array}$ \\
\hline Pertakuan teknis pengasutan & $\begin{array}{l}\text { Laki-laki dan perempuan } \\
\text { tidak dibedakan secara } \\
\text { absolut (diperlakukan adil } \\
\text { proporsional) pembedaan } \\
\text { dimungkinkan berdasarkan } \\
\text { konsep sex. }\end{array}$ & $\begin{array}{l}\text { Laki-kaki dan perempuan } \\
\text { dibedakan secara tegas } \\
\text { menurt konsep yang bias } \\
\text { jender. }\end{array}$ \\
\hline Nilai anak & $\begin{array}{l}\text { Anak laki-|aki dan } \\
\text { perempuan memiliki nilai } \\
\text { yang sama }\end{array}$ & $\begin{array}{l}\text { Anak laki-kaki bemilai lebih } \\
\text { tinggi daripada perempuan. }\end{array}$ \\
\hline $\begin{array}{l}\text { Harapan tentang masa } \\
\text { depan }\end{array}$ & $\begin{array}{l}\text { Anak laki-laki dan } \\
\text { perempuan sama-sama } \\
\text { diharapkan memiliki } \\
\text { kemandirian dan masa } \\
\text { depan yang cerah. }\end{array}$ & $\begin{array}{l}\text { Anak laki-laki diharapkan } \\
\text { memiliki kemandirian dan } \\
\text { masa depan yang cerah, } \\
\text { sedangkan wanita hanya } \\
\text { tersubordinasi kepada } \\
\text { suaminya kelak. }\end{array}$ \\
\hline
\end{tabular}


Berikut akan dijelaskan aspek-aspek pola asuh berwawasan jender yang menjadi landasan dalam penyusunan skala:

1. Wewenang dan proses pengambilan keputusan.

$\mathrm{Hal}$ ini terkait dengan pembagian wewenang antara ayah dan ibu dan proses pengambilan keputusan. Jika orang tua menunjukkan dominasi ayah dalam wewenang dan pengambilan keputusan, maka anak akan mengintemalisasi bahwa lakj-lakj lebih berkuasa dan perempuan hanya boleh mengambil wewenang dan posiși of bawah itu. Jika ada porsi yang seimbang dan demokratis antara ayah dan ibu, anak akan memahami relasi yang sejajar antara laki-laki dan perempuan.

\section{Pembagian tugas pengasuhan}

Aspek ini meliputi bagaimana cara ayah dan bu dalam membagi dan bekerjasama dalam mengasuh anak. Apakah ayah dan ibu dapat bersikapadil dan bekerjasamadalam melakukan u.gas-tugas pengasuhan. Misahya, apakah ayah terlibatjuga dalam pekerjaan-pekerjaan rumah ataukah itu hanya tugas ibu.

\section{Perlakuan teknis pengasuhan}

Hal ini berkaitan dengan cara orang tua dalam membagi tugas-tugas rumah tangga kepada anak-anaknya. Apakah dalam pembagian tersebut orang tua hanya berdasarkan pertimbangan jenis kelaminnya semata atau tidak. Apakah orang tua membedakan pembagian pekerjaan antara anak laki-laki dan perempuan atau tidak.

\section{Nilai anak}

Hal ini terkait dengan cara orang tua memperlakukan anak-anaknya, apakah ada perbedaan berdasarkan jenis kelamin atau tidak. Hal ini tentu saja akan mempengaruhi cara pandang anak tentang dirinya sendiri di hadapan lawan jenisnya. Karakter keluarga, baik sikap ayah atau ibu tentang peran seks akan berpengaruh terhadap gender identity anak. Salah satu contohnya terkait dengan bagaimana orang tua memberikan dorongan yang sama atau berbeda kepada anak lakilaki dan perempuan dalam melanjutkan sekolah dan berprestasi.

\section{Harapan tentang masa depan}

$\mathrm{Hal}$ ini terkait dengan bagaimana orang tua memberi kesempatan dan memberi dukungan perkembangan potensi anakanaknya, apakah ada pettedaan berdașar jenis kelamin atau tidak dibedakan, dan hal tersebut akan mempengaruhi kemandirian anak. Apakah masa depan hanya milik laki-laki saja atau untuk semua orang tanpa terkecuali lakilaki atau perempuan. Hal tersebut akan digeneralisasikan ke dalam keyakinan anak tentang peran seks.

Berbicara soal pola asuh berwawasan jender maka akan terkalt dengan pembicaraan soal peran jenis yang dikemukakan oleh Bem. Dalam teorinya tentang sex role, Bem (Nuryoto, 1991) menggolongkan adanya peran jenis maskulin, feminim, androgin dan tak tergolongkan. Teori mengenai pola asuh berwawasan gender ini pada dasarnya mempunyai substansi yang sama dengan pembentukan peran jeris androgin. Peran jenis androgin adalah pengkombinasian dari sifatsifat maskulin dan feminin dan disesuaikan dengan situasi.

Sex role yang selama ini berlaku sesungguhnya banyak merugikan perempuan dan laki-laki. Menurut Bem, sifat feminin yang tinggi bagi perempuan berkorelasi dengan dependensi dan kecemasan yang tinggi. Selain itu menyebabkan rendahnya harga diri dan penerimaan sosial pada diti. Sifat maskulin yang tinggi pada laki-laki berkorelasi dengan kecemasan dan neurotis yang tinggi serta penerimaan diri yang rendah. Lebih dari itu akan memunculkan pula kesombongan dan eksploitasi kepada orang lain.

Hasil penelitian Bem menunjukkan bahwa individu yang mempunyai sifat androgin memiliki sifat kemandirian yang tinggi seperti sifat maskulin dan juga mampu bersikap lemahlembut seperti sifat feminin. Sifat androgini ini dapat menolong individu agar tidak terkungkung oleh stereotipe jenis kelaminnya dalam 
bertingkah laku. Dengan adanya sifał ini individu dapat bertingkah laku sesuai dengan individual differences yang dimilikinya. Individu dangan peran jenis androgin akan lebih mudah menyesuaikan perilaku dengan keadaan disekitamya. Individu dapat membuka peluang untuk lebih berkembang karena mendapatkan kebebasan untuk mengembangkan sisi feminin maupun maskulin.

\section{HIPOTESIS}

Hipotesis yang diajukan dalam penelitian ini adalah ada hubungan antara pola asuh berwawasan jender dengan Cinderella Complex pada perempuan.

\section{METODE PENELITIAN}

\section{Variabel}

Penelitian ini menggunakan dua variabel yaitu asuh berwawasan jender sebagai variabel bebas dan Cinderella Complex sebagai variabel tergantung.

\section{Subjek Penelifian}

Subjek penelitian adalah 150 mahasiswi yang sedang menyelesaikan studi strata 1 di Fakultas Ekonomi Universitas Islam Indonesia. Subjek penelitian berada dalam rentang usia dewasa muda (19-24) tahun karena dalam usia tersebut seorang individu sudah dituntut untuk mandiri.

Karakteristik lain yang harus dimiliki subjek adalah memiliki saudara kandung berjenis kelamin laki-laki. Hal ini dimaksudkan untuk melihat aspek jender yang menyangkut laki-laki dan wanita. Adapun suku dan strata sosial ekonomi subjek tidak dibedakan

\section{Alat Ukur}

Pengambilan data dalam penelitian ini ditakukan melalui metode angket. Pola asuh berwawasan gender diungkap melalui persepsi subjek terhadap pola asuh yang ditenima dari orang tuanya dengan skala pola asuh berwawasan jender yang dimodifikasi đari Kawuri (2001). Alat ukur ini meliputi lima aspek, yaitu: wewenang dan proses pengambilan keputusan peng-așhan, pembagian tugas pengasuhan, perfakuan teknis pengasuhan, nilai anak, hara pan tentang masa depan. Skala ini hanya menyediakan đua pilihan jawaban, yaitu ya dan tidak dengan skor jawaban bergerak antara 0-1. Hal ini dimaksudkan untuk menyederhanakan diferensiasijawaban. Nilai 1 diberikan pada jawaban favorable dan nilai 0 diberikan pada jawaban unfavorable. Skala pola asuh berwawasan gender ini terdiri dari 49 butir soal dengan koefisien reliabilitas alpha sebesar 0.961 .

Cinderella Complex diungkap dengan skala yang terdiri atas enam aspek, yaitu: mengharapkan pengarahan orang lain, menghindari tantangan dan kompetisi, pengendalian dari luar (external locus of controf, mengandalkan laki-laki, rendahnya harga diri, ketakutan kehilangan femininitas. Skala Cinderella Complex ini menggunakan empat pilihan jawaban, yaitu sangat sesuai (SS), sesuai (S), tidak sesuai (TS), dan sangattidak sesuai (STS). Skor jawaban bergerak antara 1-4. Nilai tertinggi diberikan jika subjek menjawab sang at sesuai pada aitem favorable dan sangat tidak sesuai pada aitem unfavorable. Skala ini terdiri dari 47 butir soal dengan koefisien reliabilitas alpha 0,895 .

\section{Metode Analisis Dafa}

Pengujian hipotesis dalam penelitian ini menggunakan teknik analisis korelasi product moment dari Pearson.

\section{HASIL PENELITIAN}

Gambaran umum data pola asuh berwawasan jender dan dala Cinderella Complex disajikan secara deskriptif pada tabel berikut. 


\section{Tabel 3}

\section{Deskripsi data penelitian}

\begin{tabular}{lccc}
\hline \multirow{2}{*}{ VARIABEL } & \multicolumn{3}{c}{ SKOR } \\
\cline { 2 - 4 } & Min & Max & Mean \\
\hline Pola asuh berwawasan jender & 20 & 41 & 32,28 \\
Cinderefla Complex & 71 & 118 & 97,42 \\
\hline
\end{tabular}

Untuk pemberian makna atau interpretasi terhadap skor skala maka ditetapkan suatu kategorisasi yang dibuat berdasarkan sebaran hipotetik. Kategorisasi ini bersifat relatif sehingga dibagi sesuai dengan tingkat differansiasiyang kehendaki. Dengan rerata empiris variabel pola asuh berwawasan jender sebesar 32,28 maka termasuk dalam kategori sedang, yang menunjukkan bahwa sampel penelitian menerima bentuk pola asuh berwawasan jender yang termasuk dalam kategori sedang. Untuk variabel Cindereila complex, rerata empiris menunjukkan angka 97 ,42, maka termasuk dalam kategori sedang. yang menunjukkan bahwa Cinderella Complex pada sampel penelitian dalam kategori sedang.

\section{HASIL UJI HIPOTESIS}

Hasil analisis data untuk hubungan pola asuh berwawasan jender dengan Cinderella Complex menunjukkan koefisien korelasi sebesar $-0,471$ dengan $p=-0000$ Dengan taraf signifikansi $p<0,01$ berarti ada korelasi negatif yang sangat signifikan antara pola asuh berwawasan jender $(X)$ dan Cinderella Complex (Y).
Hasil dari $r=-0,471$ adalah negalif berarti bila pola asuh berwawasan jender tinggi maka Cinderella Complex akan rendah, dengan sumbangan efektif variabel pola asuh berwawasan jender terhadap Cinderella Complex sebesar 22,2\%.

\section{PEMBAHASAN}

Hasil analisis data menunjukkan bahwa korelasi yang sangat signifikan antara pola asuh berwawasan jender dan Cinderella Complex, dengan sumbangan efektif sebesar $22,2 \%$. Semakin tinggi pola asuh berwawasan gender maka semakin rendah Cinderella Complex.

Tingginya hubungan antara pola asuh berwawasan jenderdan Cinderella Complex ini menunjukkan betapa besar pengaruh lingkungan keluarga atau pola asuh orang tua terhadap tumbuh dan berkembangnya ketergantungan secara psikologis atau ketakutan akan ke-mandirian pada perempuan, sehingga tidak mempunyai keberanian untuk memanfaatkan sepenuhnya kekuatan otak dan kreativitasnya.

Hal ini sesual dengan teori Bandura yang mengemukakan bahwa praktek pengasuhan dan keadaan keluarga akan mempengaruhi 
seseorang dalam bersikap. Lebih lanjut, Hurlock (1999) mengemukakan bahwa hubungan anak dan orang tuanya akan menjadi landasan sikap terhadap orang lain, benda maupun kehidupan secara umum. Hal ini tercipta karena keluarga merupakan lingkungan yang paling dekat dan pertama kali ketika seorang anak melakukan sosialisași sebagai makhluk sosial. Secara khusus, menunt Hurlock (1999) pengaruh bu terhadap ketergantungan anak lebih besar, karena intensitas interaksi ibu dengan anak lebih banyak, dibanding-kan dengan ayah. Sebagian besar tugas pengasuhan ada pada ibu, sehingga wajar jika perilaku anak sangat dipengaruhi oleh ibunya.

Jika dalam tahapan belajar tersebut orang tua menekankan pola asuh berwawasan jender, dimana laki-laki dan perempuan diberikan peluang terhadap akses, partisipasi dan penguasaan dengan adil, maka akan terbentuk individu yang mampu mengembangkan minat dan dan kemampuannya tan pa terbelenggu akan jenis kelaminnya. Tidak akan berkembang ketergantungan secara psikis pada perempuan untuk selalu dirawat, dilindungi dan bergantung terhadap sesuatu dari luar dirinya, karena kesadaran bahwa setiap pribadi bertanggung jawab terhadap dirinya sendiri.

Pola asuh berwawasan jender tersebut dapat ditunjukkan orang tua dalam berbagai aspek pola asuh. Apabila orang tua dapat menunjukkan kesetaraan, keadilan dan tanggung jawab yang berwawasan jender antara ayah, ibu dan anak dalam proses pengambilan keputusan, pembagian tugas pengasuhan, perlakuan teknis pengasuhan, nilai terhadap anak dan harapan orang tua tentang masa depan anak, maka akan membentuk proses generalisasi anak mengenai peran seks dan relasi antara laki-laki dan perempuan yang egalitarian. Hal tersebut merupakan modal dasar dalam membentuk kemandirian dan orientasi masa depan anak.

Kemandirian merupakan salah satu faktor penting dalam membentuk kepribadian yang berkualitas. Proses pembentukan kemandirian tentunya efektif jika dimulai sejak kecil. Untuk itu pola pengasuhan yang memungkinkan terciptanya kondisi yang mendukung kemandirian, dimana memberikan peluang terhadap akses, partisipasi dan penguasaan kepada laki-laki dan perempuan terhadap berbagai hal dengan adit mutlak dibutuhkan. Kemutlakan tersebut, menurut Faraz (1996) karena proses sosialisasijender paling efektiff diberikan sejak usia dini.

Dengan sumbangan efektif pola asuh berwawasan jender terhadap Cinderella Complex sebesar $22,2 \%$, menunjukkan bahwa banyak faktor lain yang dapat mempengaruhi perkembangan ketergan-tungan dan kurangnya kemandirian pada perempuan. Faktortaktor tesebut antara lain pengaruh pendidikan secara formal, pengaruh sosial budaya yang berlaku dalam masyarakat, faktor agama dan media. Hal- hal tersebut dapat diungkap dalam penelitian selanjutnya, terutama untuk melacak variabel manakah yang akan menjadi prediktor utama tejadinya Cinderella Complex. Selain itu, bagaimana interaksi antara pola asuh dan variabel lain dalam menentukan Cinderell'a Complex juga dapat dikaji lebih jauh.

\section{DAFT.AR PUST.AKA}

Anto, M.B., Puspitasari, S., Syamsudin, M., 1998. Pola Asuh Berwawasan Gender Sebagai Upaya Peningkatan Peran Wanita. Laporan Penelitian. Yogyakarta: PSW UII.

Bardwick, J., 1971. The Psychology of Woman; A Study Or Biocultural Conflict. New York: Harper and Row.

Budiman,A., 1981. PembagianKerja Secara Seksual. Jakarta:PT Gra media.

Dowling. C., 1981. Cinderella Complex; Ketakutan Wanita akan Kemandirian. (Edisi Bahasa Indonesia). Jakar ta:Eriangga. 
Fakih, M., 1996. Analisis Gender dan Transformasi Sosial. Yogyakarta: Pustaka Pelajar Offset.

Faraz, N.J.,1996. Pola Asuh Anak Berwa wasan Gender; Dalam Perspektif Pendidikan. Makalah. Disampaikan dalam dalam Rangkaian Dies Natalis ke 53 UII. Yogyakarta: Pusat Studi Wanita UII.

Haryono, B., 2000. Kekuasaan Istri Tergan lung Suami. Surakarta: Yayasan Pustaka Cakra

Hurlock, E.B., 1999. Perkembangan Anak. Jilid II. Jakarta: Penerbit Erlangga.
Kawuri, M., 2001. Sikap Terhadap Kesetaraan Gender Ditinjau dari Pola Asuh Adil Gender. Skripsi. Yogyakarta: Fakultas Psikologi UII.

Masrun, Martono, Haryanto, F.R., Hardjito, P., Utami, M.S., Atamimi, N., Arito nang, L., Sutjipto, H., 1986. Studi Mengenai Kemandinan pada Penduduk of Tiga Suku Bangsa (Jawa, Batak, Bugis). Laporan Penelitian. Yogyakarta: Fakultas Psikologi UGM

Nuryoto, S., 1991. Perkembangan Keman dirian Remaja Ditinjau dari Tahap Perkembangan dan Peran Jenis. Tesis. Yogyakarta: Pascasarjana Fakultas Psikologi UGM. 